\title{
Biological Control of Cryphonectria parasitica in Romanian Protected Sweet Chestnut Forests
}

\author{
Dănuț CHIRA ${ }^{1}$, Valentin BOLEA ${ }^{1}$, Florentina CHIRA ${ }^{1}$, \\ Costel MANTALE ${ }^{1}$, Ioan TĂUT ${ }^{2,3}$, Vasile ŞIMONCA ${ }^{2,3 *}$, \\ Stephanos DIAMANDIS ${ }^{4}$
}

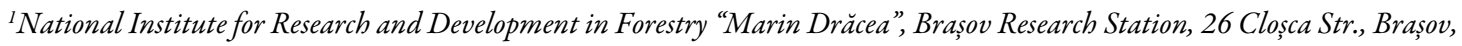 \\ Romania; chira@rdsbv.ro; valentinbolea@yahoo.com; florichr@yahoo.com \\ ${ }^{2}$ University of Agricultural Science and Veterinary Medicine, Faculty of Horticulture, Forestry Department, Cluj-Napoca, Calea Mănăștur 3-5 \\ Str., 400372 Cluj-Napoca, Romania; ioan_taut90@yahoo.com; simoncavasile@gmail.com ("corresponding author) \\ ${ }^{3}$ National Institute for Research and Development in Forestry "Marin Drăcea", \\ Cluj-Napoca Research Station, 65 Horea Str., Cluj-Napoca Romania \\ ${ }^{4}$ Forest Research Institute of Thessaloniki, NAGREF, Vasilika, 57006 Thessaloniki, Greece; stephdiamandis2@gmail.com
}

\begin{abstract}
Asiatic fungus Cryphonectria parasitica has gradually infected all chestnut habitats, forest and horticulture plantations from the most important natural centres of sweet chestnut distribution in Romania. The objectives of this work were to understand the destruction rate of chestnut habitats under $C$. parasitica pressure, and to test the efficacy of pathogen control in revitalizing these protected forests. Successive inventories of forest health status were carried out in forest districts of Maramures and Gorj counties. C. parasitica biologic control using $\mathrm{CHV} 1$ virus has been tested. The methodology includes standard laboratory and field work techniques: local hipervirulent strain identification and conversion to hipovirulence, field canker inoculation, and treatment efficacy evaluation. The fungus killed all mature chestnut trees in roughly two decades. Field inoculation has been successful on chestnut and sessile oak (fungus secondary host) in experimental plots from both target zones. This is the first time in Romania when a forest habitat is recovered by means of biological control, after a severe dieback of the old forest caused by a lethal invasive pathogen.
\end{abstract}

Keywords: Castanea sativa, canker, chestnut blight, CHV1, habitat recovery

\section{Introduction}

Castanea sativa naturally occurs in the forests of southern Europe (Conedera et al., 2004). Fossil leaves of Castanea (C. cf. sativa, C. cf. kubinyii, C. pliosativa, C. cf. crenata) dated in the Pliocene were found in many places in Romania, particularly in the north-west corner, in the volcanic chain of the Carpathians, in the same area where chestnut is present today (Givulescu, 1990; Macovei and Givulescu, 2006). In the Plio-Pleistocene chestnut diminished its European area (Mai, 1995; Svenning, 2003), and during the latest glaciation sweet chestnut was found in some refugia in southern Europe, including south Bulgaria and probable south Dobrudja (Krebs et al., 2004).

Currently, sweet chestnut forests are scattered in many small areas (without clear connections among them) in the western half of Romania, with two nuclei: Gorj County (south-west) and Maramures County (north-west), which are mentioned in medieval records (XIV ${ }^{\text {th }}$ and XVI ${ }^{\text {th }}$ century, respectively). In agreement with its long history and vigour, chestnut habitat was considered natural or at least (re)naturalised in these core centres in Romanian habitat taxonomy (Soó, 1970; Bolea, 1975; Doniță and Biriș, 2005). Sweet chestnut (Low 348 / 2003) and its forest habitats (Natura 2000 sites, natural reserves) are protected in Romania due to its rarity, economical and historical value (it is one of the medieval symbols of Baia Mare city, capital of Maramureș County).

Cryphonectria parasitica is one of the most damaging invasive fungi, destroying the forests and orchards of both American and European (sweet) chestnut (Anagnostakis et al., 1988; Robin and Heiniger, 2001). In Romania, due to the discontinuous area, chestnut blight was identified only 1984 in the experimental cultures of the Pomiculture 
Research Station of Baia Mare (Florea and Popa, 1989), after which the fungus gradually reached all the important chestnut cultures in the country (Bolea et al., 1995; Chira et al., 2003). Chestnut forests are rare and protected in Romania, which saving was a local priority, therefore the biological control of $C$. parasitica using its mycoviruses (CHV1-4) was considered the most suitable method to restore these habitats (Grente and Berthalay-Sauret 1978; Anagnostakis et al., 1988; Bisiach et al., 1994; Robin and Heiniger, 2001; Rigling and Prospero, 2017). The goals of this work were to give answers and solutions to the Romanian administrators of the protected chestnut habitats: which are the main characteristics of the destruction (disease spread rate and impact) and reconstruction methods (parasite biological control) of chestnut forests under C. parasitica pressure?

\section{Materials and Methods}

\section{Description of the study site}

Field work was carried out in the forest districts of Baia Mare, Firiza, Baia Sprie, Tăuții Măgherăuș (Maramureș County, NW Romania), and Tismana (Gorj County, SW Romania), which are the main areas with chestnut forests in Romania (Fig. 1). The local characteristics are rather similar: piedmonts of 300-500 m elevation covered by broadleaved forests (on the limit between sessile oak and European beech levels), with annual average temperature $9-9.5^{\circ} \mathrm{C}$, annual average precipitation $950-1000 \mathrm{~mm}$.

\section{Experimental design}

Sanitary condition of chestnut forests was described in inventories carried out in all the representative stands of Maramureș (57 subparcels) and Gorj (59 subparcels). Minimum of 25-50 trees/stand, according to chestnut proportion, have been analysed using transverse routes.

Biological control of $C$. parasitica based on CHV1 mycovirus was tested in 2004-2009 (Maramureş) and 20122016 (Gorj). The healing treatment intensity in experimental plots was 50 trees (sprouts) / ha $\times 3$ years consecutively in Maramureș (S1 - Baia Mare F.D., unit I, compartment 46E; S2 - Tăuţii Măgherăuş, I, 1C; S3 - Baia

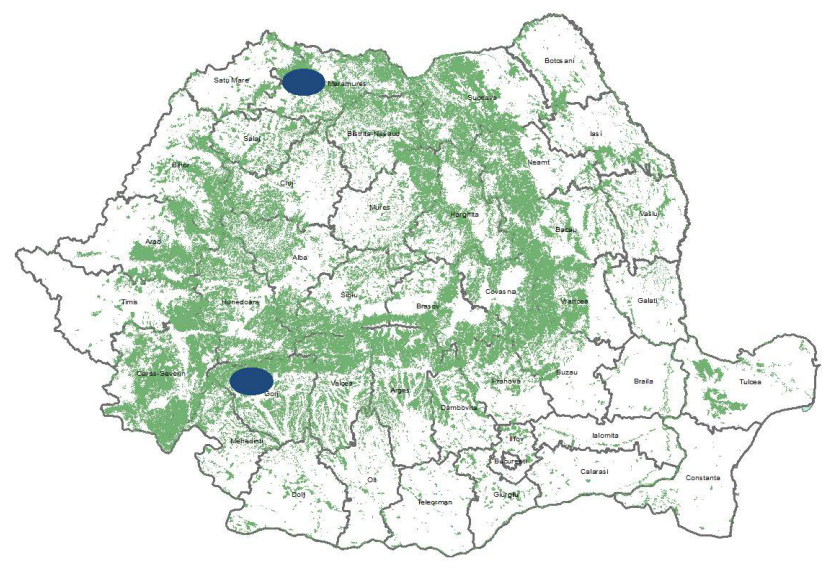

Fig. 1. Research areas (NW - Maramures, SW - Gorj) across the forest vegetation map of Romania
Mare, I, 110E), respectively 150 trees (sprouts) / ha $\times 3$ years in Gorj (S1 - Tismana, IV, 1C; S2 - Tismana, V, 44F). Treatments were tested on chestnut sprouts occurred after the previous tree generation has been killed by the aggressive fungus. For control, health status was evaluated in stands (Baia Mare/Firiza I 78, 85, 86, 98; Tismana IV 45, V 2, 38) where no inoculations have been made. Many other forest stands were just subject of fungus inoculation or virus spreading ( 25 trees / ha $\times 1$ year) according to the number of available trees, administrative problems, budget etc.

Treatment methodology includes standard laboratory and field work techniques: local hipervirulent strain identification and conversion to hipovirulence (using two strains of CHV1), field canker inoculation, and treatment efficacy evaluation (Grente and Berthalay-Sauret, 1978; Bisiach et al., 1994; Perlerou and Diamandis, 2006).

\section{Experimental procedures}

Tree condition was described according to the most important disease symptoms (bark infection presence, number of water sprouts, canker size, rate of dead crown and tree) and tree size (diameter and social class). Tree health status was evaluated according to IPC Forests methodology: 0 - healthy tree (with crown defoliation of 010\%), 1 - slight affected (15-25\%), 2 and 3 - moderate affected (with 30-45\%, respectively 50-60\% defoliation), $4-$ severe affected (65-95\%), 5 - 100\% dead (ICP Forests Manual, 2006). Brest diameter (DBH) and social position has been also recorded in order to evaluate the trees / sprouts susceptibility to chestnut blight in different development stages.

The data describing the sanitary condition of chestnut forests before the treatments were collected in 2002 in Maramuress and 2012 in Gorj. The test results of $C$. parasitica biological control (100-150 sprouts / stand) were evaluated in 2012 and 2016 in Maramureş and 2016 in Gorj. Basic data analyse and interpretation have been used.

\section{Results}

\section{Dying process}

In $2002,26.3 \%$ of the total of 57 inventoried stands (generally situated on the edge of the local chestnut area) were apparently not affected by the new disease. On the other hand, $21.1 \%$ were highly infected (blight frequency over $50 \%$ ), and $14.0 \%$ were already dead or under advanced dying process. The fungus highly infected whole chestnut forests (130 stands, covering 956.4 ha). All chestnut stands between 45 to 180 years were dead, the old trees (diameter $>28 \mathrm{~cm}$ ) have not survived, i.e. all crown and most part of the trunk have been killed, even if the tree was still living through the root sprouts and basal shoots (up to $6 \mathrm{~m}$ height on the trunk). After sanitary or salvage cuttings, chestnut forests have survived through the new generation of sprouts (vegetative regeneration), the thinner sprouts $(<3 \mathrm{~cm})$ being generally not infected (Fig. 2). The pathogen also highly affected young forests, successively killing the most vigorous and developed sprouts, which re-sprout again.

In the south-western area (Forest District of Tismana and its neighbouring zones), disease dynamic was similar to NW forests, but with a small delay. Most first infections 
634

were probably from the 1990s (undetected or minimalized); in 2004 the invasive pathogen has already killed the experimental cultures of the Pomiculture Research Station of Tg. Jiu (working point of Gureni), and the first forest outbreaks were detected (generally the forest were healthier comparing to those of Maramures in 2002). In 2012-2013 all the forests were highly infected, some of them (including Pocruia and Eroni Chestnut Reserves) being already dead.

The conservation status of the chestnut ecosystems (habitat) in the protected areas before the inoculations was unfavourable bad (totally inadequate) (Combroux and Schwoerer, 2007). The phenomenon was similar for both core-zone of Maramuress (Natura 2000 sites ROSCI 0003 and Natural Reserve 2581 "Chestnut forests of Baia Mare") and Gorj (ROSCI0129 North Western Gorj and the chestnut natural reserves "Pocruia"). All parameters were dramatically changed:

-Chestnut range is very small in Romania (3160 ha), being distributed in small woody islands, where the habitat conservation in the new stress conditions is a challenge.

-Chestnut area have been continuously diminishing: in the majority of cases chestnut proportion in the stands have been gradually decreasing, species had even disappeared from stand composition (it only remains as part of biodiversity) in some young to middle aged mixed forests of beech, hornbeam and (up to 20-30\%) chestnut.

- Forest structure and functions have been seriously degraded by the successive mass dieback of the key species in chestnut protected areas.

-Future prospects for chestnut forests were very pessimist, and the protected species are in serious danger of becoming extinct without urgent actions: biological control of the causing agent, increasing chestnut plantation, revitalisation of fruit orchards, implementation of suitable forest and orchard management, (re)raising alertness about chestnut culture and use.

\section{Healing evolution}

Biological control of C. parasitica based on CHV1 mycovirus was first tested in 2004-2008 in Maramureş. The EU12 strain has been proved to be an almost exclusive strain; EU13 was only present in a single zone (Tăuții Măgherăuș F.D.), situated close to the first identification of the pathogen.

$\because 0=1-2=3-4 \square 5$

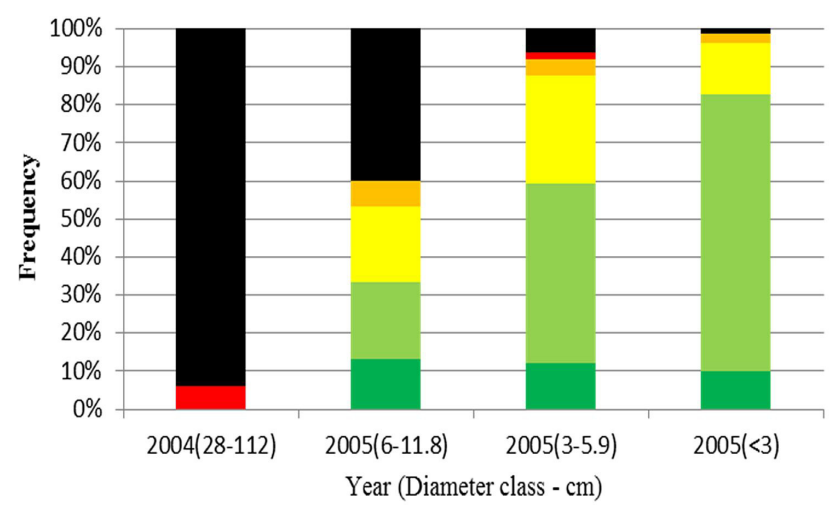

Fig. 2. Chestnut blight intensity (0-healthy, ... 5-dead tree) one year after sanitary cuttings (BM I 46E)
The potential of this method has been proved in three experimental plots, first by healing the inoculated (infection development stops in the first year) and un-treated cankers (with a clear onset starting the third year). These plots have been successively checked in 2012 and 2016, the new generations of sprouts being significantly healthier in all cases, while the untreated stands were devastated (Fig. 3).

The healing process is certified by the large majority of trees that has survived in treated plots, compared to severe loss of trees in control stands. Finally, treated stands have $79-81 \%$ healthy to relative healthy (class $0-2$ ) trees / sprouts while the un-treated stands have just 20\% plants still not affected by intense dying phenomenon. In inoculated stands, healthier trees (class 0-2) varied from 64\% (on smallest diameters - DBH - and dominated trees) to $95 \%$ (largest trees), while in un-treated stands just $4 \%(>28 \mathrm{~cm}$ $\mathrm{DBH})$ to $35 \%(<9 \mathrm{~cm} \mathrm{DBH})$ from trees are relative in good health standard (Fig. 3). Dying process was the most intense in dominated sprouts in the healed plots (Table 1).

Sessile oak (Quercus petraea) cankers (present in S2) also produced by $C$. parastica were successfully healed as well (all trees were in health class 0-1). Generally very few (all dominated) trees have died, large trees suffering just cankers or some branch loss. Several trees of European hornbeam (Carpinus betulus) have had numerous stem cankers in S1, but their crown condition was very good.

From 37 treated stands in Baia Mare F.D. the three experimental plots were advanced healed, other 18 stands moderate healed and 16 just inoculated (too old to be treated, few suitable trees were inoculated) (Figs. 4 and 5).

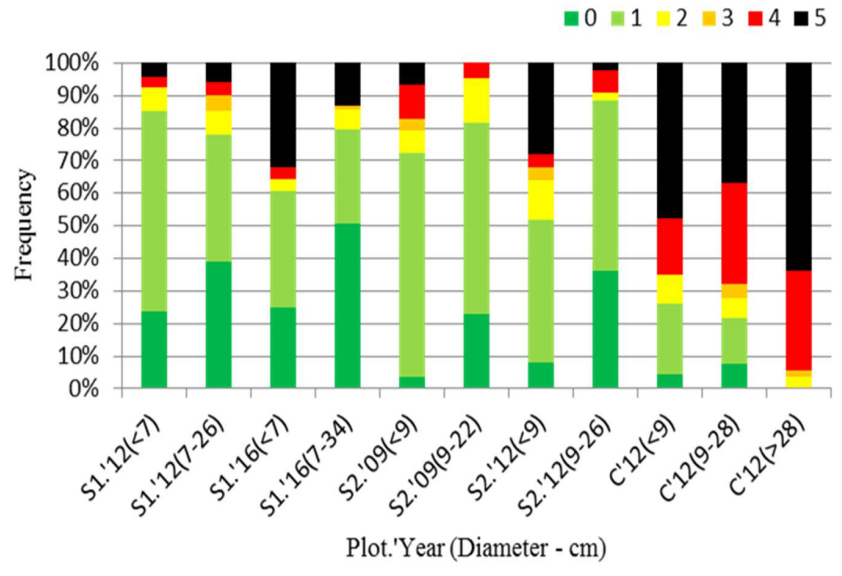

Fig. 3. Chestnut blight (0-healthy ... 5-dead trees) after biological treatment of young stands (Pots: S1, S2, and Control)

Table 1. Relationship among defoliation and tree social position and diameter in treated plots in Maramureș

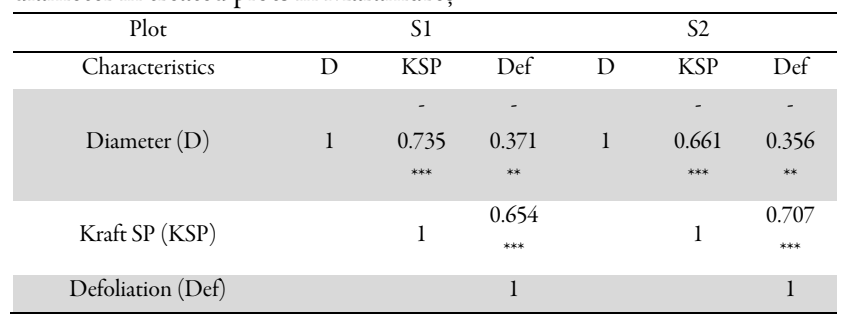




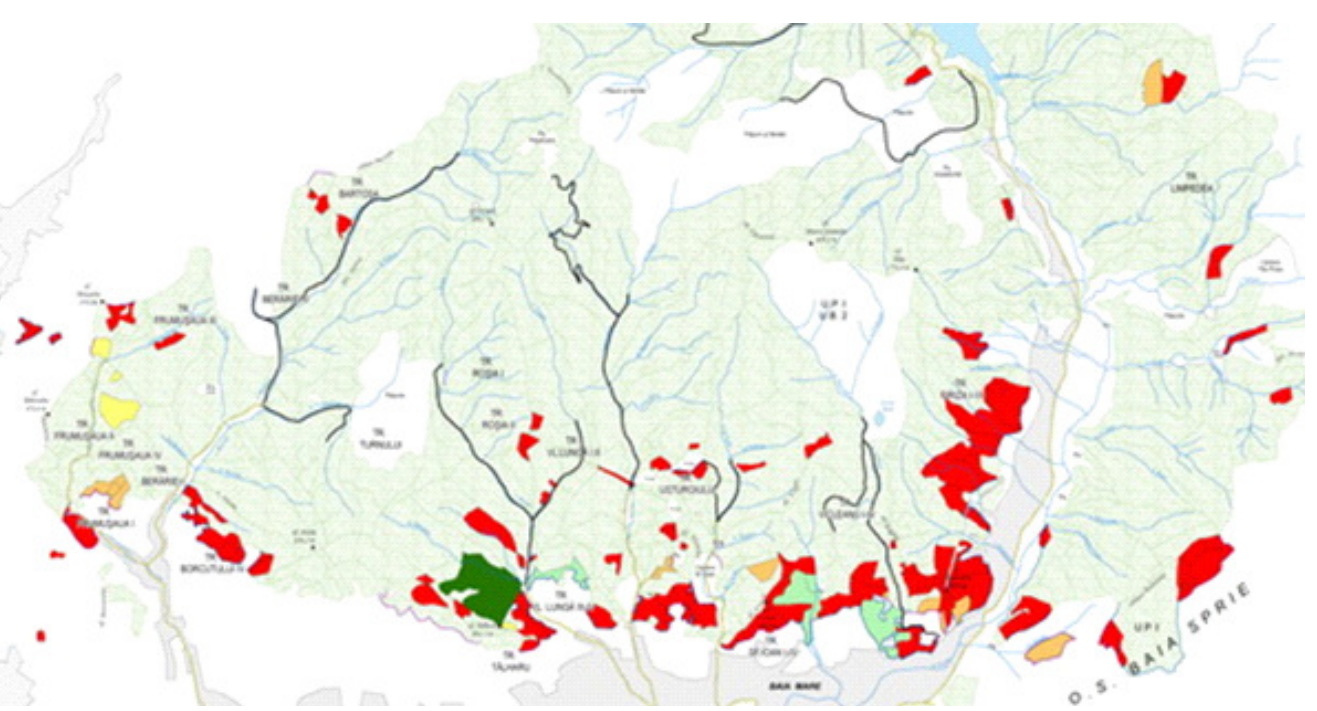

Fig. 4. Health status of chestnut stands in 2012 in Baia Mare zone (dark green: advanced healing, light green: moderate healing, yellow: inoculation for virus spreading, red: non treated with heavy infections and high chestnut mortality)

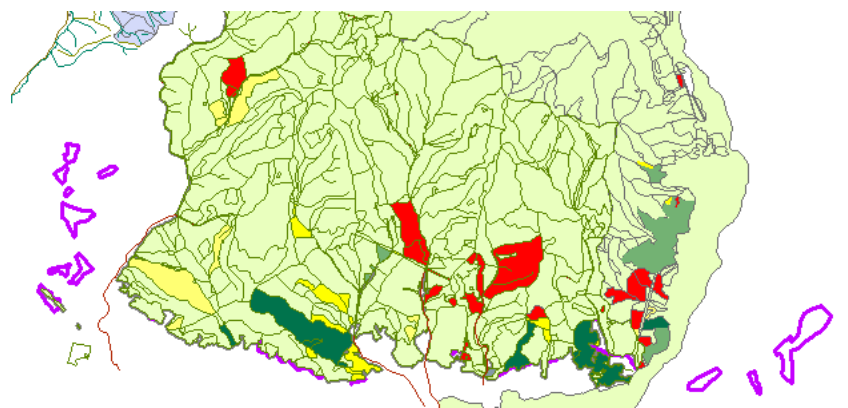

Fig. 5. Health status of chestnut stands in 2016 in Baia Mare and Firiza F.D. (dark green: advanced healing, light green: moderate healing, yellow: inoculation for virus spreading, red: non treated with heavy infections and high chestnut mortality)

Based on previous experience, in 2012-2016 the field inoculation was focused on re-establishing the conservation status of protected areas (across both core zones). More intense biological treatments were used in experimental plots of Tismana F.D., in order to urge the healing process. In other to spread the virus as much as possible, a smaller number of trees have been inoculated in stands with less suitable vegetation (old tall trees, low percentage of chestnut). Only EU12 strain has been identified in the controlled zone.

Intensive treatment (every first to third tree or one tree for each bush of stool-shoots for each stand) lead to a rapid healing of the entire stand (the large majority of trees showed infection regression and healing of non-inoculated cankers starting the year after biological control). This was possible in young dense regenerations (coppice) or plantations where chestnut was the dominant species. Before the treatment all the stands were severely infected by C. parasitica in Tismana F.D. (and surrounding forest vegetation). In un-treated stands $72 \%$ of trees were severely infected (class 3-5), and only the youngest generation $(<10$ $\mathrm{cm} \mathrm{DHB})$ was rather healthier $(70 \%$ in class $0-2)$; the majority of trees between 10 and $150 \mathrm{~cm} \mathrm{DBH}$ were dying or already dead (Fig. 6). In experimental plots, inoculation preserved the majority of sprouts (73-86\% in healthy class 0 -

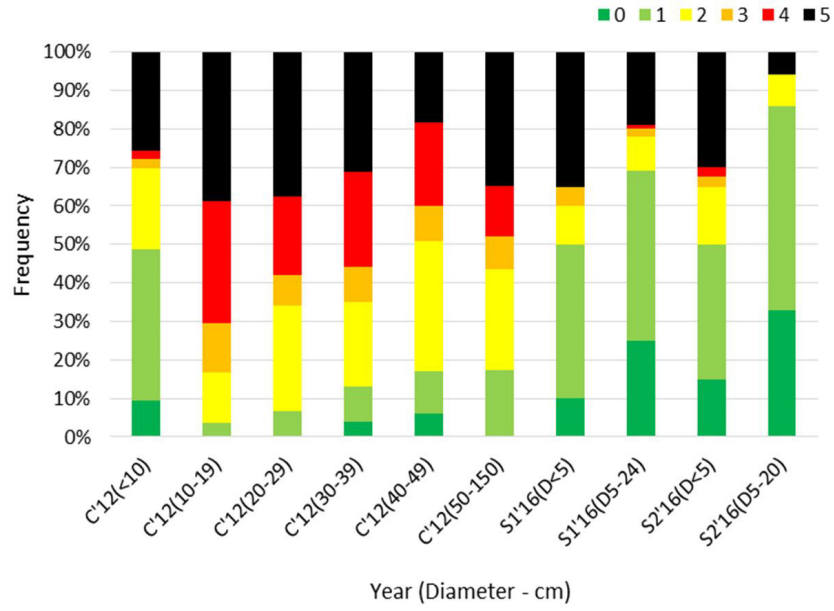

Fig. 6. Distribution of infection classes (0-healty, ... 5-dead) on different tree diameter in Tismana F.D., before (2012) and after (2016, plots S1 and S2) the biological treatment of $C$. parasitica

$2)$, the lost being predominant in smaller dominated category (35-40\%), comparing to largest ones (6-22\%) (Fig. 6).

In Tismana area the conservation actions (intensive biological treatments) had general similar results to Baia Mare: 4 advanced and 12 medium cured stands, other 21 subparcels being just inoculated for virus spreading.

Some unconventional methods have been introduced:

- Inoculation of few individuals, just for virus spreading in large areas where the proper treatment was not possible. The method has worked, and some healed trees were found 5-10 years after inoculation in many isolated stands (Figs. 45).

- Treatment of the very big cankers $(50-80 \%$ of circumference) to increase the time of releasing the virus. A satisfactory low percentage of failing (dead of treated exemplars) was found.

- Treatment without creating the hipovirulent barrier surrounding the cankers, where their position was very low 
636

(on the collar, with one part in contact with the soil) or nearby a principal axe (to stop the development in that direction, with the top of the branch or forked stem already being compromised). Both ways worked successfully (there was no difference to the classic approach).

- Inoculation of healthy bark (thin to very thick) where other method was not available. The holes were rapidly covered, so we have to test again to understand whether the method is feasible or not.

\section{Discussion}

\section{Dying process}

Experimental fruit and forest plots were the first affected by the chestnut blight in both NW and SW zones. In the 1970's and 1980's communist period, chestnut (nuts or plants) was never an item of import in Romania, although some rare scientific changes of materials or individual private initiative were possible. That suggests the hypothesis of accidental introduction (Chira et al., 2003) may be realistic, additional to the possibility of natural spreading of the fungus from the western Carpathians (SE Slovakia, N Hungary) to eastern and southern chains (NW then SW Romania), despite the very long distance from the Hungarian plantations (Radocz, 2001). This situation have changed in the last decades; Chinese chestnuts became frequent in commercial malls and seedling imports (especially from Hungary), creating the opportunity for new entries of diverse strains of $C$. parasitica in Romania.

Cryphonectria parasitica took almost two decades to spread and three decades to kill all the chestnut trees and stands (first infected generation) and orchards in a region of approximately $50 \times 10 \mathrm{~km}$ surface. Almost no resistance of chestnut trees to $C$. parasitica was found until now, although many varieties and morphological forms were described in Baia Mare (Bolea, 1975), and two different genotypes were found in Romania (Damian, 2016). A couple of trees from Tismana have shown excellent heath, future research being necessary to confirm their possible tolerance to the pathogen. Disease spreading was favoured by the Romanian silviculture: chestnut (being a very rare species) is managed according to oak and beech rotation (high forest system with over 100 years' rotation); in highly protected areas the regular cuttings are generally forbidden, and special approvals used to take time to be obtained, while in the meantime the wood quality was decreasing. A relatively similar situation is found only in other former communist countries (Conedera et al., 2004; Velichkov et al., 2010; Zlatanov et al., 2012). The delay of harvesting the dead forests led to a late vegetative regeneration of the stands that reduced the possibilities for chestnut proper resistance (through sprouts) to the invasive fungus.

The pathogen highly threatened the conservation status of this protected species and its habitat, which is considered to have a very high conservation value in Romania. In the national taxonomy, chestnut is a key species of the ecosystem R4141: Dacian-Balkan forest of sessile oak with chestnut and Genista tinctorial; and Castaneo-Quercettum in the vegetative association, Horvat 1938. This corresponds to Paleartic 41.57331 Pre-Carpathian chestnut sessile oak forest and Natura 20009260 Castanea sativa woods
(Doniță and Biriș, 2005). Bolea (1975) described several forest types dominated by or containing the sweet chestnut in Maramureș.

\section{Healing evolution}

The presence of EU12 strain of C. parasitica is characteristic to southern and south-eastern Europe (Heiniger and Rigling, 1994; Sotirovski et al., 2004; Perlerou and Diamandis 2006; Georgieva et al., 2013); however, its almost total domination (EU13 is very rare, and occurs only in Maramureș) is justified by its relatively new occurrence (one of the most recent in Europe) and probably from few accidental entries (Radocz, 2001). Similar results have been recorded in the same zones, both on chestnut and sessile oak (Radocz, 2001; Tarcali, 2007; Adamčíková et al. 2015; Görcsös et al., 2015).

The clear positive results of the pathogen treatment using CHV1 virus is typical for EU12 strain (Rigling et al., 2017), especially in the absence of the other strains. Healing a young tree is proved to be relatively easy and quick (in the same year infection stops to develop). Manually treating a stand is, however, hard and demanding, further the spread of the virus by natural pathways after the treatment took minimum two years (if treatment is very intense) to see clear results. All the little adjustments of classic field methodology seem to have interesting results, although quantitative tests need to be carried out to show their role in spreading the virus and reducing the mass infections.

The intensive treatment of infected trees was very efficient both considering ecological (in relatively young regenerations) and economical outcomes (in zones with low price of manual works).

An average loss of $16-21 \%$ of sprouts after the biological treatment of $C$. parastica is considered normal in chestnut coppices, especially those where the strain EU12 is dominant (Sotirovski et al., 2004; Heiniger and Rigling, 2009; Perlerou and Diamandis, 2010). The higher critical mass of virulent infections of $C$. parasitica before the treatment in Baia Mare and Tismana may also explain these good results of biological control with hipovirulent strains (Griffin, 1986). The presence in Baia Mare zone of the EU13 strain and especially the uncontrolled new entries of (chest)nuts and seedlings may threaten the fragile balance established through the biological control of $C$. parasitica in protected chestnut areas from Romania, similarly to disease dynamics in central and western Europe (Cortesi and Milgroom, 1998; Robin et al., 2010; Bryner and Rigling, 2012; Zamora et al., 2012; Bryner et al., 2014; Feau et al., 2014).

Differentiation between the effects of natural competition and infection process in dying trees is not easy to be understood. In stands affected for a long period by the hipervirulent strains of $C$. parasitica, only the very young chestnut sprouts are relative healthy, while in healed (hipovirulent) chestnut stands, younger sprouts are first to succumb due to intense competitions on basic resources in dense coppices (Zlatanov et al., 2012).

Saving a protected rare woody species and recovering some protected forest ecosystem from unfavourable bad conservation status caused by an invasive pathogen represent a first across Romanian territory. 


\section{Conclusions}

In 30 years of occurrence in Romania Cryphonectria parasitica conquered all the chestnut area, ruining the fruit orchards and seriously threatening the protected forest ecosystems. All middle age to old trees have been killed. Several campaigns for the biological control of the invasive fungus in young chestnut regeneration have had very promising results. A good part of treated chestnut protected forest had a remarkable evolution. Intensive treatments have rapidly controlled the disease, and low intensive inoculation was used to spread the virus in unsuitable stands for canker treatment. This is the first time in Romania that a part of a forest habitat is recovered by means of biological control, after a severe dieback of the old forest caused by a lethal invasive pathogen.

\section{Acknowledgements}

This work was supported by several projects: Conservative management for 4070 and 9260 habitats of ROSCI0129 North of Western Gorj (NORTHWEST GORJ); Starting the implementation of integrated management of sweet chestnut reserve Natura 2000 site ROSCI0003; Healing the chestnut stands in Maramures (Integrated control, silvicultural and biological, of sweet chestnut and sessile oak) and Technical assistance for experimental ecological reconstruction of the chestnut stands using integrated (biological and silvicultural) of the chestnut blight.

\section{References}

Adamčková K, Ondrušková E, Kádasi-Horáková M, Botu M, Kobza M, Achim G (2015). Distribution and Population Structure of the Chestnut BlightFungus in Romania. Plant Protection Science 51(3):141-149.

Anagnostakis SL, Chen B, Geletka GM, Nuss DL (1988). Hypovirus transmission to ascospore progeny by field released transgenic hypovirulent strain of the chestnut blight fungus $C$. parasitica. Phytopathology 86:301-310.

Bisiach M, De Martino A, Intropido M (1994). Lotta biologica contro il cancro del castagno, esperienze su larga scala in differenti regioni italiane. In: Quacquarelli A (Ed). Lotta biologica et integrata - Piante forestali 5355.

Bolea V (1975). Contributions to the typology study of chestnut forests from hilly piedmonts of Baia Mare (in Romanian). Revista Pădurilor 1:2429.

Bolea V, Mihalciuc V, Chira D, Bud N, Pop V (1995). Chestnut blight Cryphonectria parasitica (Murrill.) Barr in Valea Borcut vegetative seed orchard, Forest District of Baia Mare (in Romanian). Revista Pădurilor 1:2429.

Bryner SF, Riging D (2012). Virulence not only costs but also benefits the transmission of a fungal virus. Evolution 66:2540-2550.

Bryner SF, Prospero S, Rigling D (2014). Dynamics of Cryphonectria hypovirus infection in chestnut blight cankers. Phytopathology 104(9):918-925.
Chira D, Bolea V, Chira F, Mantale C (2003). Sanitary state of Castanea sativa and possibilities of biological control of Cryphonectriaparasitica (in Romanian). Revistade Silviculturăşi Cinegetică 17-18:79-80.

Combroux I, Schwoerer C (2007). Evaluation of conservation state of habitats and species of common interest in Romania - Methodologic guide (in Romanian).Ed Balcanic, Timişoara.

Conedera M, Krebs P, Tinner W, Pradella M, Torriani D (2004). The cultivation of Castanea sativa (Mill.) in Europe: from its origin to its diffusion on a continental scale. Vegetation History and Archaeobotany 13:161-179.

Conedera M, Krebs P (2008). History, present situation and perspective of chestnut cultivation in Europe. Acta Horticulturae 784:23-27.

Cortesi P, Milgroom MG (1998). Genetics of vegetative incompatibility in Cyyphonectria parasitica. Applied and Environmental Microbiology 64(8):2988-2994.

Damian VL (2016). Characterisation of genetic variability of chestnut in Romania (in Romanian). $\mathrm{PhD}$ thesis, USAMV Cluj-Napoca.

Doniţă N, Biris IA (2005). R4141 Daco-balcanice forest of sessile oak (Quercus petraea) and chestnut (Castanea sativa) with Genista tinctoria (in Romanian) In: Doniță N (Ed). Romanian habitats. Ed Tehnică Silvică.

Feau N,Dutech C,Brusini J,Rigling D, Robin C (2014). Multiple introductions and recombination in Cryphonectria hypovirus 1: perspective for a sustainable biological control of chestnut blight. Evolutionary Applications 7(5):580-596.

Florea S, Popa I (1989). Diseases of the edible chestnut reported in the fruit growing area of Baia Mare (in Romanian). In: Scientific Research for FruitProduction 1969-1989 pp365-372.

Georgieva M, Zlatanov T, Petkov P, Rosnev B, Georgiev G, Mirchev P (2013). Effect of Cryphonectria parasitica (Murrill.) Barr. on the health condition of chestnut (Castanea sativa Mill.) on the northern slopes of Belasitsa Mountain. Forest Science 1(2):73-87.

Givulescu R (1990). The fossil flora of the Miocene of Chiuzbaia (in Romanian).Ed Academiei.

Görcsös G, Irinyi L, Radócz L, Tarcali G, Sándor E (2015). Diversity of Cryphonectria parasitica populations from the Carpathian Basin. Acta Microbiologica et Immunologica Hungarica 62(3):247-266.

Grente J, Berthalay-Sauret S (1978). Biological control of chestnut blight in France. In: McDonald WL, Cech FC, Luchok J, Smith C (Eds). Proceedings of the American Chestnut Symposium. West Virginia University Press, Morgantown WV pp 30-34.

Griffin GJ (1986). Chestnut blight and its control. Horticulture Review 8:291-336.

Griffin GJ (2000). Blight control and restoration of the American chestnut. Journal of Forestry 98:22-27.

ICP Forests (2006). Manual on methods and criteria for harmonized sampling, assessment, monitoring and analysis of the effects of air pollution on forests. Part II. Retrieved 2017 April 8 from https://www.icp-forests.org/pdf/manual/2000/Chapt2_compl06.pdf.

Heiniger U, Riging D (1994). Biological control of chestnut blight in Europe. Annual Review of Phytopathology 32:581-599. 
638

Heiniger U, Riging D (2009). Application of the Cryphonectria hypovirus (CHV-1) to control the chestnut blight, experience from Switzerland. ActaHorticulturae 815:233-246.

Krebs P, Conedera M, Pradella M, Torriani D, Felber M, TinnerW (2004). Quaternary refugia of the sweet chestnut (Castanea sativa Mill.): an extended palynological approach. Vegetation History Archaeobotany 13:145-160.

Krstin L, Katanic Z, Ježic M, Poljak I, Nuskern L, Matkovic I, Idžojtic M, Curkovic-Perica M (2016). Biological control of chestnut blight in Croatia: an interaction between host sweet chestnut, its pathogen Cryphonectria parasitica and the biocontrol agent Cryphonectria hypovirus 1. Pest ManagementScience 73(3):582-589.

Macovei G, Givulescu R (2006). The present stage in the knowledge of the fossil flora at Chiuzbaia, Maramureş, Romania. Carpathian Journal of Earth andEnvironmental Sciences 1(1):41-52.

Mai DH (1995). Tertiäre Vegetationsgeschichte Europas. Methoden und Ergebnisse. 691 S, 257 Abb Gustav Fischer Verlag, Jena, Stuttgart, New York.

Perlerou C, Diamandis S (2006). Identification and geographic distribution of vegetative compatibility types of Cryphonectria parasitica and occurrence of hypovirulence in Greece. Forest Pathology 36:413-421.

Perlerou C, Diamandis S (2010). Spread of introduced hypovirulence vs. natural hypovirulence in chestnut blight. Acta Horticulturae 866:393398.

Radócz L (2001). Study of subpopulations of the chestnut blight (Cryphonectria parasitica) fungus in the Carpathian basin. Forest, Snow and Landscape Research 76(3):368-372.

Riging D, Prospero S (2017). Cryphonectria parasitica, the causal agent of chestnut blight: invasion history, population biology and disease control. Molecular Plant Pathology. doi:10.1111/mpp.12542.

Robin C, Heiniger U (2001). Chestnut blight in Europe: Diversity of Cryphonectria parasitica, hypovirulence and biocontrol. Forest, Snow and Landscape Research 76(3):361-367.
Robin C, Lanz S, Soutrenon A, Riging D (2010). Dominance of natural over released biological control agents of the chestnut blight fungus Cryphonectria parasitica in southeastern France is associated with fitnessrelated traits. Biological Control 53:55-61.

Soó R (1970). The Hungarian flora and vegetation system, a geographic handbook (in Hungarian).IV, Budapest.

Sotirovski K, Papazova-Anakieva I, Grunwald NJ, Milgroom MG (2004). Low diversity of vegetative compatibility types and mating type of Cryphonectria parasitica in the southern Balkans. Plant Pathology 53:325-333.

Svenning J-C (2003). Deterministic Plio-Pleistocene extinctions in the European cool-temperate treeflora. Ecology Letters 6:646-653.

Tarcali G, Radocz L (2006). Identification of natural infection of Quercus spp. by the chestnut blight fungus in North Romania, near Baia Mare. Proceedings of 4th International Symposium "Natural Resources and Sustainable Development", October 10-11, 2006, Oradea, Romania pp 395-401.

Tarcali G (2007). Examination of Cryphonectria parasitica in Carpathian Basin. PhD Thesis Univ. Debrecen. Retrieved 2016 May 14 from https://dealib.unideb.hu/dea/bitstream/handle/2437/79553/tezis_an gol.pdf? sequence $=6$.

Velichkov I, Hinkov G,Zlatanov T, Zlatanova M, Hristova H (2010). Area distribution dynamics of Castanea sativa forests on the northern slopes of Belasitsa Mountain. Silva Balcanica 11(1):21-26.

Zamora P, Martín AB, Riging D, Diez JJ (2012). Diversity of Cryphonectria parasitica in western Spain and identification of hypovirus-infected isolates. Forest Pathology 42(5):412-419.

Zlatanov T, Gogushev G, Georgieva M, Hinkov G, Velichkov I (2012). State of chestnut (Castanea sativa Mill.) in mixed deciduous thickets in Belasitsa Mountain. Forest Science 1(2):23-36. 